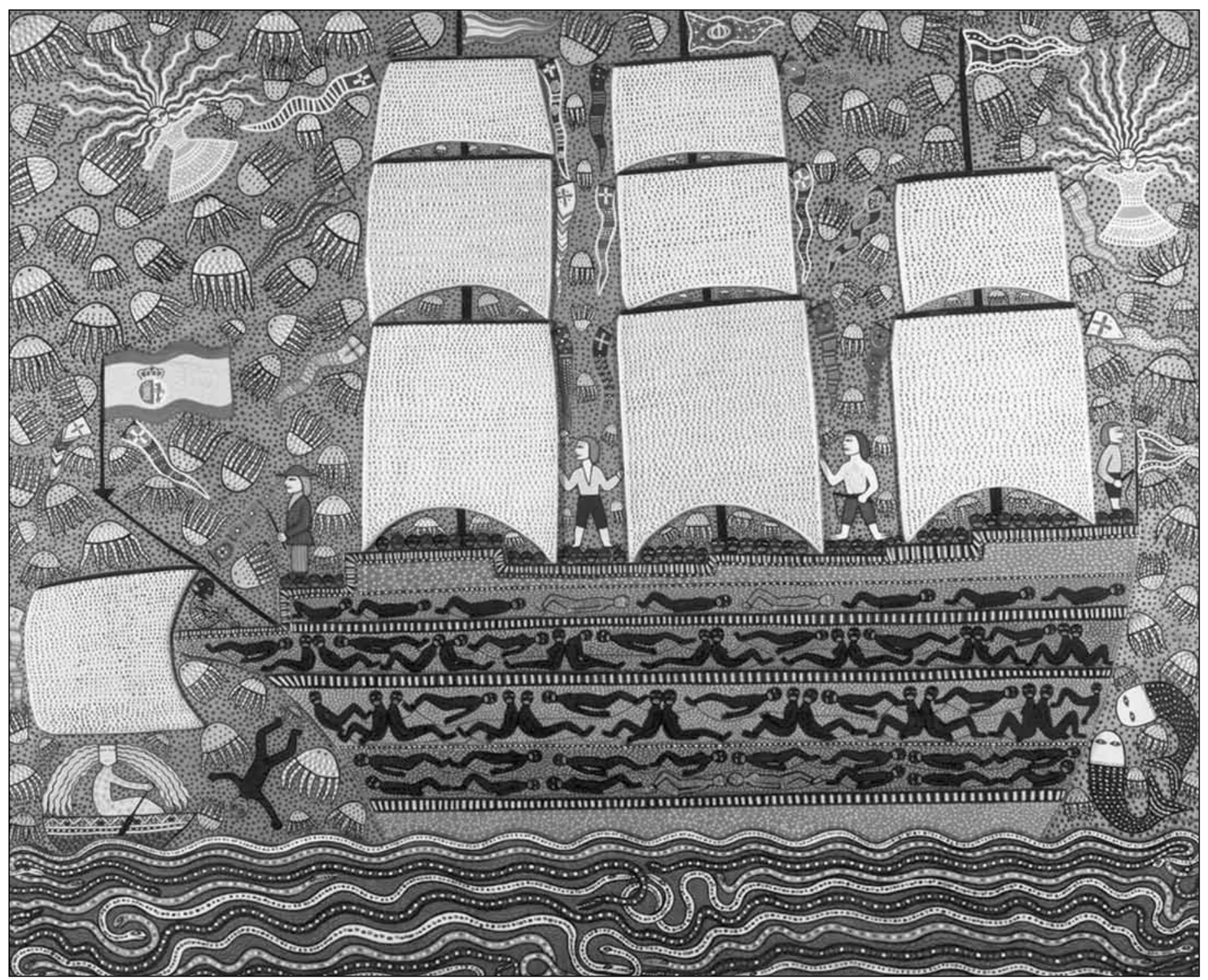

Manuel Mendive. Barco negrero. 1976. Oleo sobre madera. 102 × 126 cm. Colección Museo Nacional de Bellas Artes. La Habana, Cuba. Cortesía de Mendive Art Studio. 


\title{
Luis Palés Matos y Aimé Césaire: entre África y América en un barco libertario
}

\author{
MERCEDES LÓPEZ-BARALT \\ Universidad de Puerto Rico
}

\section{RESUMEN}

A partir de la obra del jamaiquino Claude McKay, del martiniqués Aimé Césaire y del puertorriqueño Luis Palés Matos, Jean-Claude Bajeux propuso - desde una perspectiva comparatista - que la negritud antillana se rige por cuatro leyes: el ritmo y la sonoridad, la denominación (el inventario sistemático del mundo afroantillano), la inversión de los valores de la cultura oficial y la amplificación del sujeto (del yo al nosotros). López-Baralt propone un análisis de algunos textos poéticos de Luis Palés Matos y Aimé Césaire, ya que comparten, además de las cuatro leyes mencionadas, un símbolo plurivalente inserto en el campo semántico de la liberación y ligado históricamente a la diáspora africana en las Antillas: el barco.

Palabras clave: Luis Palés Matos, Aimé Césaire, diáspora, negritud, barco, Vanguardia.

\section{ABSTRACT}

Based on the literary works of Jamaican writer Claude McKay, the poet Aimé Césaire from Martinique, and Porto Rican poet Luis Palés Matos, Jean-Claude Bajeux proposed - from a comparative perspective - that Antillean négritude is ruled by four laws: rhythm and sonority, denomination (the systematic inventory of the Afro-Antillean World), inversion of the values of the official culture and the amplification of the subject (from self to us). López-Baralt analyzes poems by Palés Matos and Césaire that, in addition to meet the four aforementioned laws, share a polyvalent symbol inserted on the semantic field of liberation and historically tie to the African Diaspora in the Antilles: The Ship.

Keywords: Luis Palés Matos, Aimé Césaire, Diaspora, négritude, ship, Avant-Gardes.

Hace unas décadas, el poeta haitiano Jean Claude-Bajeux, defensor aguerrido de los derechos humanos en su país natal, fijaba en Antilia retrouvé (1983) los parámetros de la poesía negrista del Caribe tanto hispánico como anglófono y francófono. A partir de la obra del jamaiquino Claude McKay, del martiniqués Aimé Césaire y del puertorriqueño Luis Palés Matos, Bajeux propuso - desde una perspectiva comparatista - que la negritud antillana se rige por cuatro leyes: el ritmo y la sonoridad, la denominación (el inventario sistemático del mundo afroantillano), la inversión de los valores de la cultura oficial y la amplificación del sujeto (del yo al nosotros). Uno de los hallazgos más valiosos del libro reside en el descubrimiento del símbolo que hermana a estos tres poetas vanguardistas: la danza como esencia del alma negra, tema de poemas como «The Harlem Dancer» (McKay: Harlem Shadows, 1922), Cabier d'un retour au pays natal (Césaire, 1939) y varios de $\mathrm{Pa}$ -

\author{
Mercedes López-Baralt \\ Puertorriqueña. Tiene dos maes- \\ trías, una en literatura de la Uni- \\ versidad de Puerto Rico y otra en \\ antropología, de Cornell, donde \\ obtuvo su doctorado. También tie- \\ ne un Doctorado Honoris Causa \\ de la Universidad de Puerto Rico, \\ donde se desempeñó como catedrá- \\ tica y donde dirigió el Seminario \\ Federico de Onís. Es autora de $E l$ \\ mito taíno (1977). El retorno del \\ Inca rey (1987), Icono y conquista: \\ Guaman Poma de Ayala (1988), \\ La gestación de Fortunata y Jacinta \\ (1992), Guaman Poma, autor y \\ artista (1993). El barco en la bote- \\ lla: la poesía de Luis Palés Matos \\ (1997). Orfeo mulato: Palés ante \\ el umbral de lo sagrado (2009), El \\ Inca Garcilaso, traductor de cultu- \\ ras (2011) y Una visita a Macondo \\ (manual para leer un mito) (2011), \\ entre otros.
}

Luis Palés Matos y Aimé Césaire: entre África y América en un barco libertario

MERCEDES LÓPEZ-BARALT 


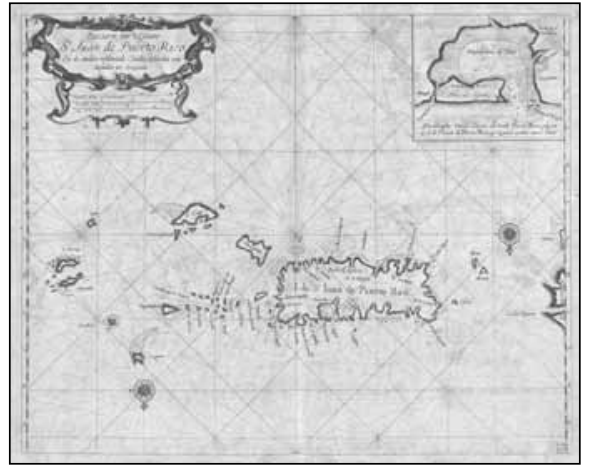

Lionel Pincus and Princess Firyal Map Division, The New York Public Library. "Pascaerte van't Eylant St. Juan de Puerto Rico." The New York Public Library Digital Collections. 1680.

A partir de ahora cito a Palés por mi edición crítica de su poesía (1995). Vale notar que el Tuntún se publica por primera vez en 1937 y por segunda vez, ampliado, en 1950. Los poemas citados en este ensayo son del primer Tuntún a menos que advierta lo contrario; es decir, que sólo pertenezcan al segundo Tuntún o a otra etapa de la obra palesiana.

Luis Palés Matos y Aimé Césaire: entre África y América en un barco libertario

MERCEDES LÓPEZ-BARALT el barco. epitafio: lés: «Danzarina africana» (1917), «Danza negra» y «Majestad negra», del Tuntún de pasa y grifería $(1937,1950)$ y la «Plena del menéalo» (1952). Se trata de una metáfora que subvierte los valores del mundo occidental, con su culto a la razón y su obsesión por el trabajo productivo. Y que de ninguna manera alude al infantilismo primitivo que le adjudica Europa. Porque la danza negra es una actividad lúdica protagonizada por cuerpos gozosos en comunión con la naturaleza, cuya sensualidad apunta a la fecundidad y al futuro. Hoy quisiera volver a dos de los poetas estudiados por el maestro haitiano, Palés y Césaire, ya que comparten, más allá de las cuatro leyes mencionadas, un símbolo plurivalente inserto en el campo semántico de la liberación y ligado históricamente a la diáspora africana en las Antillas:

Y comienzo con Luis Palés Matos, pionero de la negritud literaria caribeña desde la publicación de «Danzarina africana» y consagrado desde 1937 por su Tuntún de pasa $y$ grifería. Poco antes de su muerte en 1959, esbozó unos versos que publiqué por primera vez en 1995 y que hoy podemos leer como

Estoy y no estoy ya ido

en esta barca de ron.

Se apagan onda, sonido,

y a lo lejos desvaído

suena un profundo acordeón...

trombón que gime escondido

dentro de mi corazón. (690)1

El poema, sin fecha, nos deja una importante lección de lectura. La barca -indudable arquetipo literario - funde la endogénesis (sus múltiples sentidos en la poesía de Palés) con una intertextualidad múltiple. La imagen convoca asociaciones del mundo clásico ( $\mathrm{Ca}$ ronte) y del medieval (la nave de los locos). Pero el calificativo de ron entronca a la barca palesiana también con la modernidad. El simbolismo francés dice presente en la barca de ron a través, no sólo de «Le beau navire» de Baudelaire, sino también del poema de Rimbaud, «Le bateau ivre». La herencia simbolista del fragmento palesiano se revela además en el empleo de la sinestesia: el acordeón suena «desvaído», como si el sonido estuviera compuesto por colores.

La barca de ron, por su movimiento oscilante, evoca la danza, y es aun otra manera de nombrar el ritmo, que funda la poesía. Ritmo esencial para la negritud y que en este texto deviene redoble fúnebre mediante el acento agudo de una vocal oscura (la o): ron, acordeón, corazón). La barca de ron es también, cómo dudarlo, Puerto Rico (sus contornos geográficos configuran la silueta de una nave); isla devastada - sobre todo en las décadas del treinta y el cuarenta- por el monocultivo cañero. Es además la «Mulata-Antilla» del Tuntún y de la «Plena del menéalo»; en esta última, el poeta describe la mulatez del arquetipo de la mujer-barco con el verso «babas de miel te acaoban», recordando la melaza como base del ron (615). Y es, en última instancia, el cuerpo del poeta aficionado al tórrido elixir antillano. Esta última interpretación suscita dos imágenes poderosas: la del barco inmóvil en un mar de melaza (variante de la escena del sueño infantil que abre su novela autobiográfica Litoral: reseña de una vida inútil), de 1949, en la que el niño Palés se hunde en un pantano sin poder cobrar las garzas que su puntería de cazador había alcanzado) y la del barco dentro de una botella. Ambas condensan los dos grandes núcleos de la imaginería palesiana, polarizada en el pantano y el barco: el destino del poeta está en su perenne oscilar entre tierra y mar, prisión y vuelo, aquí y allá, realidad y fantasía.

Pero, ¿y el primer verso del poema? Meciéndose en el ritmo musical del octosílabo del antiguo romancero, «Estoy y no estoy ya ido» manifiesta la perenne oscilación que caracteriza, no sólo la poesía de Palés, sino su psique dubitativa, escéptica. Y que adquiere nombre en el memorable «Ten con ten», del Tuntún, que celebra la mulatez de su isla:

Y así estás, mi verde antilla,

en un sí es que no es de raza,

en ten con ten de abolengo/que te hace tan antillana... Al ritmo de tus tambores/tu lindo ten con ten bailas, una mitad española

y otra mitad africana. (564)

Pues la mezcla de razas deviene ahora fusión del ser y no ser que problematiza tanto la existencia del poeta, a punto de emprender el viaje final, como la posibilidad misma de 
su poesía, que es y no es al mismo tiempo: el sonido se apaga y se esconde, a la vez que suena y gime. Ten con ten que impone - en su afirmación de la ambigüedad - las posibilidades de una lectura polivalente de la obra de Luis Palés Matos.

Lectura que he intentado desde diversas perspectivas en El barco en la botella: la poesía de Luis Palés Matos (1997), «La africanía mítica en el negrismo del poeta Luis Palés Matos» (2005) y Orfeo mulato: Palés ante el umbral de lo sagrado (2009). Hoy me interesa volver al primero, porque en él ensayé una mirada abarcadora de la poesía palesiana desde la noción del símbolo dominante, propuesta por un antropólogo escocés muy literario: Victor Turner. Se trata de un símbolo persistente, ambiguo, que expresa significados fundamentales para el poeta. En su caso, como ya lo he mencionado, se trata de un símbolo dual, el de la polarización entre el barco como vuelo (viaje, libertad, fantasía, poesía) y la tierra como cerco que deviene pantano o melaza, ron que paraliza, arenal que asfixia). En la obra palesiana hay poemas emblemáticos de los dos polos de este símbolo dual. En Canciones de la vida media, de 1925, el poeta se siente ahogado no sólo por la atmósfera provinciana de su ciudad natal, Guayama, en una isla que Luis Rafael Sánchez nombrara en La guaracha del Macho Camacho como «colonia sucesiva de dos imperios» (13), sino asfixiado por la sequedad de la tierra desértica de sus campos, como aparece en el siguiente fragmento de «Topografía» ${ }^{2}$ :

Ésta es la tierra estéril y madrastra

en donde brota el cacto.

Salitral blanquecino que atraviesa

roto de sed el pájaro;

con marismas resecas espaciadas

a extensos intervalos,

y un cielo fijo, inalterable y mudo

cubriendo todo el ámbito.

Miedo, desolación, asfixia. Todo

duerme aquí sofocado

bajo la línea muerta que recorta

el ras rígido y firme de los campos.

Ésta es la tierra donde vine al mundo.

- Mi infancia ha ramoneado

como una cabra arisca por el yermo

rencoroso y misántropo -

Ésta es toda mi historia: sal, aridez, cansancio,

una vaga tristeza indefinibe,

una inmóvil fijeza de pantano,

y un grito, allá en el fondo,

como un hongo terrible y obstinado,

cuajándose entre fofas carnaciones

de inútiles deseos apagados. (421-422)

Si la tierra ahoga a Palés hasta el límite de la impotencia sexual, sugerida genialmente al final del poema, el barco, por el contrario, significa liberación para el poeta. Consideremos la prefiguración del arquetipo de la mujerbarco en Tembandumba de la Quimbamba, la protagonista de «Majestad negra». El poema anticipa, por más de dos décadas, el slogan norteamericano de los años sesenta, black is beautiful:

Por la encendida calle antillana

va Tembandumba de la Quimbamba

- rumba, macumba, candombe, bámbula-

entre dos filas de negras caras.

Ante ella un congo - gongo y maraca -

ritma una conga bomba que bamba.

Culipandeando la Reina avanza,

y de su inmensa grupa resbalan

meneos cachondos que el gongo cuaja

en ríos de azúcar y de melaza.

Prieto trapiche de sensual zafra,

el caderamen, masa con masa,

exprime ritmos, suda que sangra,

y la molienda culmina en danza.

Por la encendida calle antillana

va Tembandumba de la Quimbamba.

Flor de Tortola, rosa de Uganda,

por ti crepitan bombas y bámbulas;

por ti en calendas desenfrenadas

quema la Antilla su sangre ñáñiga.

Haití te ofrece sus calabazas;

fogosos rones te da Jamaica;

Cuba te dice: ¡dale, mulata!

Y Puerto Rico: ¡melao, melamba!

¡Sús, mis cocolos de negras caras!

Tronad, tambores; vibrad, maracas.

Por la encendida calle antillana

- rumba, macumba, candombe, bámbula -

va Tembamdumba de la Quimbamba. (536)

La reina africana ${ }^{3}$, con su contundente nombre, onomatopéyico de tambores, puede ser cualquier trabajadora negra de la caña que sale a la calle en un día de fiesta a incitar con su contoneo a los hombres que la codician. Pero lo interesante del poema está
Vale hacer constar que más allá de la referencialidad histórica, el poema también exhibe un importante nivel de referencialidad literaria. Porque el paisaje que describe, si bien se ajusta perfectamente a la realidad de la región del sureste de Puerto Rico, que en su aridez contrasta con el verdor exuberante de norte de la isla, también se puede leer como un paisaje literario y más aún, psíquico. Y es que se trata de una versión antillana del spleen de Baudelaire, que otorga título a varios poemas de Les fleurs du mal, libro de cabecera del poeta. Nótese también que en el poema coexisten la tierra seca y el pantano (manglares y salitrales) que caracterizan a Guayama como zona costera.

Vale destacar la referencialidad histórica del nombre. Tembandumba fue una reina africana, como consta en el libro de Antonio Cavazzi que cita Bajeux (1983:164): Istorica descrizione de tre regni Congo Matamba e Angola (Bolonia, 1687). Lo que nos lleva a subrayar una de las aportaciones de Palés a la negritud: el recordarnos que África no se puede resumir en el estereotipo común del negro primitivo, porque su historia en la que proliferan reinos poderosos, incluso imperios - es rica y compleja.

Luis Palés Matos y Aimé Césaire: entre África y América en un barco libertario

MERCEDES LÓPEZ-BARALT 


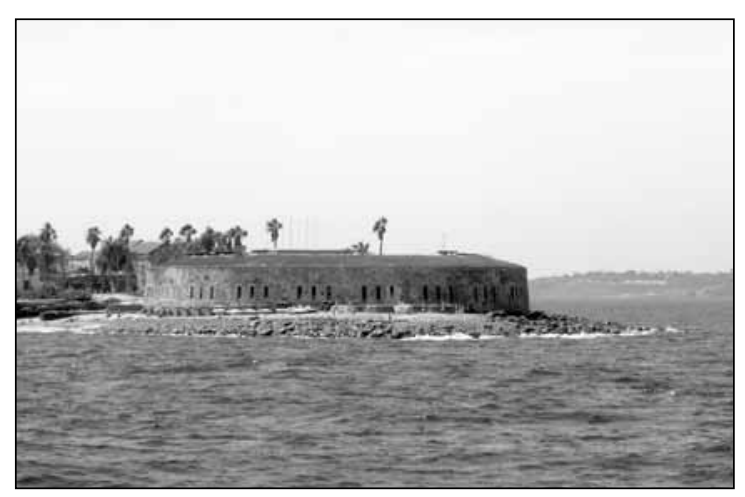

Llegada a la îl de Goree. Vista de Fort d'Estrées. Île de Gorée. Dakar, Senegal. Fotografía de Ciara Rivera.

\section{4}

Ver Alberto Muguercia (1971).

Luis Palés Matos y Aimé Césaire: entre África y América en un barco libertario

MERCEDES LÓPEZ-BARALT en el hecho de que el cuerpo de Tembandumba, metaforizado en el trapiche cañero, convierte el duro trabajo de la molienda en danza gozosa, en un acto inolvidable de liberación. Los versos de «Majestad negra» nos evocan el famoso «Son de la Ma Teodora», breve poema cubano decimonónico protagonizado por una mulata ya mítica ${ }^{4}$ :

¿Dónde está la Ma Teodora?/Rajando la leña está. ¿Con su palo y su bandola?/Rajando la leña está.

¿Dónde está, que no la veo?

Rajando la leña está.

Rajando la leña está.

Rajando la leña está.

Como lo nota Roberto González Echevarría (1980), la Ma Teodora cimarronea el trabajo esclavo hasta hacerlo baile gozoso. Porque rajar la leña no sólo alude a cortarla para hacerla útil, sino a las grietas que los pasos reiterados y frenéticos del baile abren en el tablado de madera donde se danza.

Ahora bien, he propuesto que Tembandumba esboza el arquetipo palesiano de la mujer-barco, que se concreta de manera rotunda en «Mulata-Antilla», la «Plena del menéalo» $\mathrm{y}$ «Puerta al tiempo en tres voces» (1949). Palés nos lo advierte con una pincelada fugaz, pero elocuente. Me refiero al coloquialismo caderamen, que alude a caderas amplias y voluptuosas, y que evoca de inmediato a otro sustantivo de igual estructura, esta vez alusivo a la noción de barco: velamen, el conjunto de velas de una embarcación. Ya veremos cómo la mulata se convierte en velero.

Si en «Majestad negra» la heroína danza para salvarse de la esclavitud, en la «MulataAntilla» del segundo Tuntún se convertirá en emblema de la liberación de nuestras islas de la codicia imperial: «eres inmensidad libre y sin límites» (599); «porque eres tú, mulata de los trópicos, la libertad cantando en mis Antillas» (600). Pero es en el nivel explícitamente político, sin duda, que la metáfora del barco enarbola la bandera libertaria con más brío. La mujer-barco preside una alegoría rotundamente antiimperialista en la «Plena del menéalo», parodia humorística de la creación, en 1952 - la misma fecha de composición del poema- del «Estado Libre Asociado» en Puerto Rico. Fórmula política que intentó entonces, sin lograrlo, enmascarar la situación colonial que aún persiste en la isla. Vale citar algunos fragmentos del poema:

Bochinche de viento y agua...

sobre el mar

está la Antilla bailando

- de aquí payá, de ayá pacá,

menéalo, menéalo-

en el huracán.

En el raudo movimiento

se despliega tu faldón

como una vela en el viento;

tus nalgas son el timón

$\mathrm{y}$ tu pecho el tajamar;

vamos, velera del mar,

a correr este ciclón,

que de tu diestro marear

depende tu salvación.

¡A bailar!

Dale a la popa el valiente

pase de garbo torero, que diga al toro extranjero

cuando sus belfos enfile

hacia tu carne caliente:

-Nacarile, nacarile,

nacarile del Oriente- .

Dale a la popa, danzando, que te salva ese danzar del musiú que está velando al otro lado del mar.

Ondule tu liso vientre melado en cañaveral; al bulle-bulle del viento libre piernas tu palmar; embalsamen tus ungüentos azahares de cafetal; y prenda fiero bochinche en el batey tropical, invitando al huele-huele tu axila de tabacal.

Mientras bailes, no hay quien pueda cambiarte el alma y la sal.

$\mathrm{Ni}$ agapitos por aquí, ni místeres por allá.

Dale a la popa, mulata, proyecta en la eternidad 
ese tumbo de caderas

que es ráfaga de huracán,

y menéalo, menéalo,

de aquí payá, de ayá pacá,

menéalo, menéalo,

¡para que rabie el Tío Sam! (613-616)

La intención subversiva del poema, tan evidente, va mucho más allá del desafío antiimperialista de la Mulata-Antilla convertida en mujer-barco. La entrelínea nos permite hacer otra lectura, a partir de la ironía que caracteriza al más grande de los poetas puertorriqueños: el repudio de la esclavitud. En el contexto de la poesía negrista, el barco alude a una realidad inescapable: los esclavos de África llegaron a América en él, por la razón contundentemente geográfica del océano que separa ambos continentes. De ahí que en dicho contexto la noción de barco, nave, o, en este caso, velero, esté cargada: consciente o inconscientemente, no podemos menos que evocar al barco negrero, aunque Palés lo subvierta, convirtiéndolo en barco libertario. En otros contextos - los temas del amor, la muerte, la poesía - la cosa es otra. Porque la noción del barco entra de inmediato, sin interferencias negativas, en el campo semántico de la esperanza, aludiendo a vuelo, a libertad ${ }^{5}$, a trascendencia.

La poesía negrista ha reconocido explícitamente el propósito siniestro que sirvió el barco en la infame trata esclavista que convirtió a las Antillas en islas mulatas. Así lo testimonia otro protagonista de la negritud literaria, Nicolás Guillén, en uno de los poemas de Tengo ${ }^{6}$ :

Vine en un barco negrero.

Me trajeron.

Caña y látigo el ingenio.

Sol de hierro./Sudor como caramelo.

Pie en el cepo. (41)

Pero Palés es un poeta mítico y alegórico; por ello no aborda directamente el tema esclavista como lo hace su contraparte cubano, cuya poética es mimética y realista. De ahí que en la «Plena del menéalo», el cruel barco negrero que transportó a la Mulata-Antilla desaparece, para cederle el lugar a una nave timoneada por ella misma, que confronta, tienta, desafía y burla al imperio que sustituyó al español en estas aguas: el norteamericano.
Aun así, vale apuntar que nuestro poeta conoció de primera mano la tragedia de la diáspora africana, como lo podemos inferir de su recreación de la mitología yoruba en el Tuntún de pasa y grifería ${ }^{7}$. Porque mamó en la leche los cantos de la cocinera negra Lupe, en su hogar infantil. En Litoral, el poeta hace constar la presencia en Guayama de una cultura negra viva, de la que rescata el rito del baquiné para describirlo, en el capítulo XVII, con la riqueza de detalles de una narración antropológica. En dicho capítulo nos revela, de una pincelada, el origen de Lupe, a la que le había dedicado el capítulo XI. Nos dice así: «(Vieja, buena e inolvidable Lupe, con el espíritu -zombí o muñanga - desencarnado, vuelto ya a los bosques de tu remota Guinea originaria, ¡cuántas veces me quedé dormido en tu regazo al rumor de ese canto maravilloso, de aquel adombe profundo que todavía suena en mi corazón!)» (Obras 2: 88). De esta cita vale destacar dos elementos: por una parte, el hecho de que la tradición oral africana ingresó en el inconsciente del poeta de manera poderosa, pues la recibió en la duermevela de su temprana niñez, lo que explica que en el futuro constituyera parte indeleble de su imaginario de adulto. Por otra, la noticia de que Lupe viene de Guinea, lo que apunta a la posibilidad de su origen yoruba.

Claro que la voz Guinea nombra varias regiones: un país del mismo nombre entre Senegal, Liberia, Costa de Marfil y Sierra Leona; el Golfo de Guinea, en la que el Atlántico baña con sus aguas las costas de Dahomey, Ghana, Camerún, Guinea Ecuatorial, Costa de Marfil, Togo, Gabón y Nigeria; y Guinea Ecuatorial, pequeña república bordeada por Gabón, $\mathrm{Ca}-$ merún y el Golfo de Guinea. Cabe pues, la posibilidad de que Palés se refiera al Golfo de Guinea, que sirve de costa a Nigeria, lugar de origen de la cultura yoruba, aunque ésta se extiende por un área mayor de la costa occidental africana. Porque la inmigración africana llegó a Puerto Rico de la Costa de Oro, conocida como «la costa esclavista», que comprende la región de las Guineas. Que los esclavos llegaran de allí no significa, sin embargo, que procedieran de dicha zona. Para abonar más a la tragedia de la diáspora africana, la trata esclavista borró los orígenes de los negros que importaba a América, ya que, como nos advierte Carmen Vázquez Arce, «se le atribuía al esclavo, como nación, el lugar de su embarco y no necesariamente el de su procedencia real» (30). De ahí que la pérdida de la identidad La equivalencia entre barco y libertad la sentó Espronceda, con el estribillo de su "Canción de pirata»: "Que es mi barco mi tesoro, /que es mi dios la libertad, /mi ley, la fuerza y el viento, /y mi única patria, la mar».

6

La metáfora visionaria «sol de hierro» la toma Guillén de un poema del Tuntún palesiano, "Danza negra», que comienza así: «Calabó y bambú. / Bambú y calabó. / El Gran Cocoroco dice: tu-cu-tú. / La Gran Cocoroca dice: to-co-tó. / Es el sol de hierro que arde en Tombuctú. / Es la danza negra de Fernando Póo. / El cerdo en el fango gruñe: pru-pru-prú. / El sapo en la charca sueña: cro-cro-cró. / Calabó y bambú. /Bambú y calabó» (507).

7 Abordé este tema en Orfeo mulato.

Luis Palés Matos y Aimé Césaire: entre África y América en un barco libertario

MERCEDES LÓPEZ-BARALT 


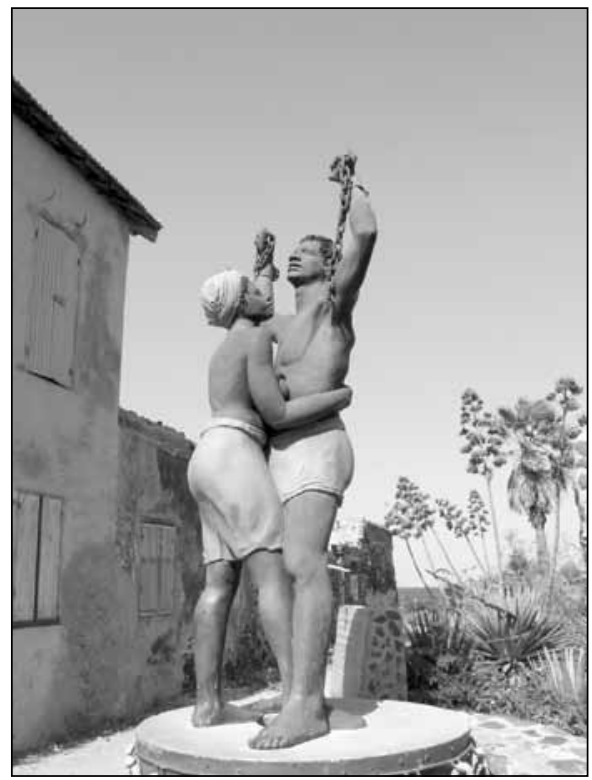

Statue de la Liberátion de l'Esclavage. Île de Gorée. Dakar, Senegal. Fotografía de Ciara Rivera. colectiva sea otra más de las consecuencias estremecedoras de la trata de esclavos.

Sirva lo hasta aquí dicho como preámbulo para considerar una singular coincidencia entre Luis Palés Matos y Aimé Césaire en el contexto de la negritud caribeña, en lo que concierne a la imagen libertaria del barco, tan distante de la visión realista del barco negrero. Abordemos ahora el poema más célebre del poeta martiniqués, que evidencia importantes puntos de contacto con la poesía palesiana: Cabier d'un retour an pays natal, publicado fragmentariamente en París en 1939 en la revista Volonté. Nacido en la Martinica de antepasados esclavos, Césaire conoce en París a Léopold Senghor, poeta senegalés junto Así lee el original:

Au bout du petit matin bourgeonnant $d^{\prime}$ anses frêles les Antilles qui ont faim, les Antilles grêlées de petite vérole, les Antilles dynamitées d'alcool, échovées dans la boue de cette baie,

dans la poussière de cette ville sinistrement échovées. (22)

9

El original lee:

Calme et berce ô ma parole l'enfant qui ne sait pas que la carte du printemps est toujours à refaire

les herbes balanceront pour le bétail vaisseau doux de

l'espoir

le long geste d'alcool de la houle les étoiles du chaton de leur bague jamais vue couperont

les tuyaux de l'orgue de verre du soir puis

répandront sur l'extrémité riche de ma fatigue

des zinnias

des coryanthes... (94)
Luis Palés Matos y Aimé Césaire: entre África y América en un barco libertario

MERCEDES LÓPEZ-BARALT al que funda en 1934 la revista L'Etudiant Noir. Desde entonces se sintió africano, y acuñó la palabra negritud para nombrar un movimiento vanguardista que capitanearía desde Francia con su Cuaderno de un retorno al país natal como estandarte. Se trata de un extenso poema a su raza, cuyo primer movimiento es un canto a las Antillas; el segundo, una toma de conciencia; y el tercero, la celebración de los condenados de la tierra, para usar la célebre frase del psiquiatra revolucionario martiniqués Frantz Fanon.

Por cierto, que el retorno al que alude el título del poema es tanto a la Martinica (en términos biográficos, el país natal de su autor), como a Âfrica (en términos raciales y simbólicos, su país de origen). El poeta dirá que «a fuerza de pensar en el Congo / me he convertido en un Congo rumoroso / de bosques y de ríos». En una sorprendente coincidencia con Palés, Césaire expresa su versión del «barco en la botella», porque antes de anunciar su libertad al final del poema, las Antillas metaforizan su orfandad histórica al asumir la forma de barco encallado en el lodo. Y cito de la primera página de su Cuaderno ${ }^{8}$ :

Al final del amanecer abrotoñado de ensenadas frágiles las Antillas hambrientas, las Antillas picadas de viruelas, dinamitadas de alcohol, encalladas en el cieno de esta bahía, en el polvo de esta ciudad siniestramente encalladas. (Bartha 23)
Como en la poesía palesiana, aquí las Antillas son a la vez tierra (islas de alcohol) y barco que encalla en una bahía cenagosa. La diferencia entre ambos poetas en cuanto al empleo de la imagen bipolar está en la celebración que hace Palés de la bahía de melaza que acoge con dulzura la nave de la isla flotante cual barco, y la visión desoladora y terrible que del Caribe ofrece el poema del martiniqués. Cito los versos que abren el poema «Mulata-Antilla» del segundo Tuntún, en el que el poeta viaja de pasajero en la mujer-barco:

\author{
En ti ahora, mulata, \\ me acojo al tibio mar de las Antillas. \\ Agua sensual y lenta de melaza, \\ puerto de azúcar, cálida bahía, \\ con la luz en reposo/dorando la onda limpia, \\ y el soñoliento zumbo de colmena \\ que cuajan los trajines de la orilla. (598)
}

Pero el Cuaderno de retorno al país natal de Césaire coincidirá con la «Plena del menéalo» de Palés, al proponer la misma equivalencia entre el barco y la esperanza. Se trata de un barco que también navega en un mar de alcohol, como el del epitafio palesiano, pero con el mismo destino optimista de la citada «Plena»?:

¡Oh palabra mía calma y acuna al niño que no sabe que

el mapa de la primavera debe rehacerse siempre

las hierbas se balancearán para el ganado dulce

barco de

la esperanza

el largo ademán de alcohol de la ola

las estrellas del sello de su sortija nunca vista

cortarán los tubos del órgano de cristal del atardecer luego esparcirán sobre la extremidad rica de mi fatiga sinias

coriantos... (Bartha 95; mis itálicas)

La apoteosis libertaria estallará luminosa en el final triunfante del poema, cuando el sujeto lírico (alter ego de Césaire, desde luego) asume, como señala Bajeux, la voz de la profecía para anunciar un mundo mejor para el negro antillano. Y cuando se autolegitima abrazando el plural de la primera persona -el nosotros de la negritud - tras declararse «el maestro de las danzas»:

el negrero cruje por todas partes... Su vientre se 
convulsiona y resuena... La horrible tenia de su cargamento roe los intestinos fétidos del extraño niño de pecho de los mares.

Y ni el júbilo de las velas hinchadas ${ }^{10}$ como un abultado bolso de doblones, ni las jugarretas hechas a la tontería peligrosa de las fragatas policiacas le impiden oir la amenaza de sus gruñidos intestinos

En vano para olvidarse de ello el capitán cuelga en su palo mayor al negro más gritón, o lo echa al mar, o lo entrega al apetito de sus molosos

La negrería que huele a cebolla frita ${ }^{11}$ vuelve a encontrar en su sangre derramada el sabor amargo de la libertad

Y está de pie la negrería

La negrería sentada

inesperadamente de pie

de pie en la cala

de pie en los camarotes

de pie en el puente

de pie en el viento

de pie al sol

de pie en la sangre

$$
\text { de pie }
$$

libre

de pie y no como una pobre loca en su libertad y su indigencia marítimas girando en la deriva perfecta y aquí está:

más inesperadamente de pie

de pie en los cordajes

de pie ante el timón

de pie ante la brújula

de pie ante el mapa

de pie bajo las estrellas

de pie

libre

y el navío lustral hiende impávido las aguas desplomadas

¡Y ahora su pudren nuestras borlas de ignominia!

por el mar restallante de mediodía

por el sol abrotoñado de medianoche

escucha gavilán que tienes las llaves del oriente

por el día desarmado

por el tiro de piedra de la lluvia

escucha escualo que velas en el horizonte

escucha perro blanco del norte, serpiente negra del

mediodía

que rematáis el cinturón del cielo

Todavía hay un mar por cruzar

oh todavía un mar por cruzar

para que yo invente mis pulmones

para que el príncipe se calle

para que la reina me bese

todavía un viejo mar por asesinar un loco por libertar

para que mi alma brille ladre brille

ladre ladre ladre

y que chille la lechuza mi bello ángel curioso.

¿El maestro de las risas?

¿El maestro del silencio formidable?

¿El maestro de la esperanza y de la desesperación?

¿El maestro de la pereza? ¿El maestro de las danzas?

¡Soy yo!

y por eso, Señor

los hombres de cuello frágil

recibe y percibe fatal calma triangular

Y para mí mis danzas

mis danzas de mal negro

para mí mis danzas

la danza rompe-argolla

la danza salta-prisión

la danza es-hermoso-y-bueno-y-legítimo-ser-negro

Para mí mis danzas y salta el sol en la raqueta de mis manos

pero no el sol desigual ya no me basta

enróscate, viento, alrededor de mi nuevo crecimiento

pósate en mis dedos medidos

te entrego mi conciencia y su ritmo de carne

te entrego los fuegos donde se asa mi debilidad

te entrego la cadena múltiple

te entrego el pantano

te entrego el intourist del circuito triangular ${ }^{12}$

devora desea

te entrego mis palabras abruptas

devora enróscate

y enroscándote abrázame con un más vasto estremecimiento

abrázame hasta el nosotros furioso

abraza, abraza NOS ${ }^{13}$

pero habiéndonos igualmente mordido

hasta la sangre de nuestra sangre mordido,

abraza, mi pureza sólo se enlaza con tu pureza

pero entonces abraza

como un campo de apretados filaos

en la noche

nuestras multicolores purezas

y enlaza, enlázame sin remordimientos

enlázame con tus inmensos brazos de arcilla luminosa

enlaza mi negra vibración al ombligo mismo del

mundo

enlaza, enlázame, áspera fraternidad.... (Bartha 127129) 14

¿Acaso no es ésta la propuesta de Palés en la «Plena del menéalo», cuando la MulataAntilla asume el timón de su propia nave, enfilándola contra el tío Sam hasta marearlo? En el fragmento final también vemos la fusión del barco con el pantano, ya que la nave
10

Nótese que, como en la «Plena del menéalo», la nave es un velero.

11

La asociación del aroma del negro con la cebolla frita la encontramos en un poema de Palés, el ya citado "Ten con ten», de 1932. El poeta apostrofa así a la Mulata-Antilla: «Pasarías ante el mundo/por civil y ciudadana, /si tu axila - flor de sombra -/ no difundiera en las plazas/el rugiente cebollín/que sofríen tus entrañas». (1995:564).

12

Posible alusión al periplo entre África, Martinica y Francia.

13

Aquí Césaire abraza por un momento fugaz el nosotros de la «áspera fraternidad» antillana. Aunque tanto él como Palés suelen emplear el yo en su poesía, Bajeux explica que en la negritud hay una intrusión implícita de pronombre plural en el pronombre de la primera persona (305) es decir, la vocación de dar voz a una colectividad silenciada.

14

Aquí el original:

le négrier craque de toute part... Son ventre se convulse et résonne... L'affreux ténia de sa cargaison ronge les boyaux fétides de l'étrange nourrison des mers!

Et ni l'allégresse des voiles gonflées comme une poche de doublons rebondie, ni les tours joupés à la sottise dangereuse des frégates policières ne l'empêchen d'entendre la menace de ses grondements intestins

En vain pour s'en distraire le capitaine pend à sa grand'vergue le négre le plus braillard ou le jette à la mer, ou le livre à l'appétit de ses molosses

La négraille aux senteurs d'oignon frit retrouve dans son sang répandu le goùt amer de la liberté

Et elle est debout la négraille

la négraille assise

inattendument debout

debout dans la cale

debout dans les cabines

debout sur le pon

debout dans le ven

debout dans le solei

debout dans le sang

debout libre

debout et non point pauvre folle dans sa liberté et son dénouement maritimes girant en la dérive parfaite et la voici:

plus inattendument debout

debout dans le cordages

debout à la barre

debout à la boussole

Luis Palés Matos y Aimé Césaire: entre África y América en un barco libertario

MERCEDES LÓPEZ-BARALT 
debout à la carte

debout sous les étoiles

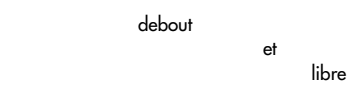

et le navire lustral s'avance impavide sur les eaux écroulées.

Et maintenant pourrisent nos flocs d'ignominie!

par la mer cliquetante de midi

par le soleil bourgeonnant de minuit

écoute épervier qui tiens les clefs de

l'orient

par le jour desarme

par le jet de pierre de la pluie

écoute squale qui veille sur l'occident

écoutez chien blanc du nord, serpent noir du midi

qui achevez le ceinturon du ciel

Il y a encore une mer à traverser

oh encore une mer à traverser

pour que $j^{\prime}$ invente mes poumons

pour que le prince se taise

pour que la reine me baise

encore un vieillard à assassiner

un fou à delivrer

pour que mon âme luise aboie luise

aboie aboie aboie

et que hulule la chouette mon bel ange

curieux.

Le maître des rires?

Le maître du silence formidable?

Le maître de l'espoir et du désespoir?

Lemaîtredelaparesse? Lemaîtredesdanses? C'est moi!

et pour ce, Seigneur

les hommes au cou frêle

reçois et perçois fatal calme triangulaire
les hommes au cou fâle

Et à moi mes danses

mes danses de mauvais nègre

à moi mes danses

la danse brise-carcan

la danse saute-prison

la danse il-est-beau-et-bon-et-légitime

d'être-nègre

A moi mes danses et saute le soleil sur la raquette

de mes mains

mais non l'inégal soleil ne me suffit plus mais non l'inégal soleil ne me suffit plus
enroule-toi, vent, autour de ma nouvelle croissance

pose-toi sur mes doigts mesurés je te livre les feux où brasille ma faiblesse je te livre le chain-gang

ie te livre le marais

je te livre l'intourist du circuit triangulaire je te livre l'intor
dévore veut

dévore veut
je te livre mes paroles abruptes

dévore et enroule-toi

et $t^{\prime}$ enroulant embrasse-moi d'un plus

vaste

frisson

embrasse-moi jusqu'au nous furieux

embrasse, embrasse NOUS

mais nous ayant également mordus

jusqu'au sang de notre sang mordus!

embrasse, ma pureté ne se lie qu'à ta

pureté

mais alors embrass

comme un champ de justes filaos

le soir

nos multicolores puretés

te lie, lie-moi sans remords

lie-moi de tes vastes bras à l'argile lumi-

neuse

lie ma noire vibration au nombril même du monde

lie, lie-moi, fraternité âpre... (120-128)

Luis Palés Matos y Aimé Césaire: entre África y América en un barco libertario

MERCEDES LÓPEZ-BARALT encierra en su vientre la tenia del cargamento de esclavos. Pero gracias a la poesía, el barco negrero ha de transformarse en "navío lustral» y los esclavos apiñados en sus fétidas bodegas saldrán a la luz, asumirán el timón, manejarán la brújula, el mapa y los cordajes, para llegar a un destino de liberación. Y lo harán -como los negros y mulatos de nuestro Palés - danzando jubilosos. En medio de esta danza entregarán las cadenas que los ataron y el pantano que pretendía tragarlos.

La coincidencia entre Palés y Césaire en proponer la imagen bipolar barco/pantano con el sentido de libertad/prisión (en que Palés se adelanta al martiniqués, ya que estas equivalencias son y con mucho anteriores a la poesía del Tuntún de 1937, mientras que Césaire publica en 1939 su Cuaderno) es ciertamente notable. Pero más allá de filiación - cosa que no podemos probar - habría que ver la diferencia de sentido entre ambos campos semánticos. En el caso palesiano es la propia psique de un poeta que vive el ten con ten de la oscilación perenne entre su pesimismo innato y su anhelo utópico de liberación, la que produce esta imagen bipolar de tierra y barco que da coherencia a su poesía. En el de Aimé Césaire se trata de la historia de la africanía en las Antillas, de negros que vienen en barcos a cultivar la caña que produce la melaza, el azúcar y el ron. En ambos poemarios el barco significa liberación, pero si bien Césaire subvierte ante nuestros propios ojos el barco negrero hasta convertirlo en navío lustral, Palés casi siempre ve el barco como liberador. En el caso del martiniqués, dicho motivo está indefectiblemente ligado a la historia antillana. En el del puertorriqueño, la nave, símbolo antiimperialista en la «Plena del menéalo» y emblema de libertad en «MulataAntilla», tiene una evidente referencialidad histórica. Pero va más allá, hasta convertirse en un símbolo plurivalente, porque también es autorreferencial. En sus múltiples transformaciones míticas, la mujer-barco termina aludiendo a la inefalibilidad de la poesía. Es el caso de la heroína que culmina la poesía palesiana en su etapa final, y que protagoniza los poemas del amor y de la muerte que hoy conocemos como el ciclo de Filí-Melé. En «Puerta al tiempo en tres voces», el poeta, que ansía apresar a la musa que cifra en su ser la poesía, le pregunta:

Y ahora, a qué trasmundo, perseguida serás, si es que eres? ¿Para qué ribera

huye tu blanca vela distendida

sobre mares oleados de quimera? (626)

Porque el vuelo poético es precisamente un viaje tan liberador como imposible hacia la trascendencia, hacia la belleza, hacia otros mundos; entre ellos, el África que Palés nunca conoció, pero que quiso recrear - elevándola a estatura mítica- en el Tuntún de pasa y grifería.

\section{Bibliografía}

Anónimo: Son de la Ma Teodora. www.pbs. org/buenavista/musica/a_ma-teodora.html

Bajeux, Jean-Claude: Antilia retrouvé. Claude McKay, Luis Palés Matos, Aime Césaire, poètes noires antillais. Nouveau/ Brunswick/Quebec, Agence de Coopération Culturelle et Technique. Editions Caribéens, 1983.

Césaire, Aimé: Cabier d'un retour au pays natal/Cuaderno de un retorno al país natal. Edición bilingüe (francés/español) con prólogo de Agusti Bartha. México, Era, 1969.

Espronceda, José de: www.analitica.com/ biblio/espronceda/pirata.asp

González Echevarría, Roberto: «Literature of the Hispanic Caribbean». Latin American Literary Review, VIII, 16, Spring/ Summe 1980:1-20.

Guillén, Nicolás: Tengo. Montevideo, Editorial El Siglo Ilustrado, 1968.

López-Baralt, Mercedes: El barco en la botella: la poesía de Luis Palés Matos. San Juan de Puerto Rico, Editorial Plaza Mayor, 1997.

- «La africanía mítica en el negrismo del poeta Luis Palés Matos». Para decir al Otro: literatura y antropología en nuestra América. Madrid, Iberoamericana Vervuert, 2005: 345-461.

- Orfeo mulato: Palés ante el umbral de lo sagrado. San Juan, Editorial de la Universidad de Puerto Rico, 2009.

Muguercia, Alberto: «Teodora Ginés: ¿mito o realidad histórica?» Revista de la Biblioteca Naiconal José Martí, La Habana, septiembre/diciembre 1971: 53-85.

Palés Matos, Luis: La poesía de Luis Palés Matos. Edición crítica de Mercedes LópezBaralt. San Juan, Editorial de la Universidad de Puerto Rico, 1995.

- Obras (1914-1959). Tomo I: Poesía, Tomo II: Prosa. Edición de Margot Arce de 
Vázquez. San Juan, Editorial de la Universidad de Puerto Rico, 1984.

Sánchez, Luis Rafael: La guaracha del Macho Camacho. Buenos Aires, Ediciones de La Flor, 1976.

Turner, Victor: The Forest of Symbols. Aspects of Ndembu Ritual. Ithaca, New York/Londres, Cornell University Press, 1974.
Vázquez Arce, Carmen: «Sobre lo mítico-heroico ancestral en el Tuntún de pasa y grifería de Luis Palés Matos». Actas del Congreso Internacional Luis Palés Matos. Guayama, Universidad Interamaricana, 1998.

Fecha de recepción: 14/05/2014

Fecha de aceptación: 07/10/2014 


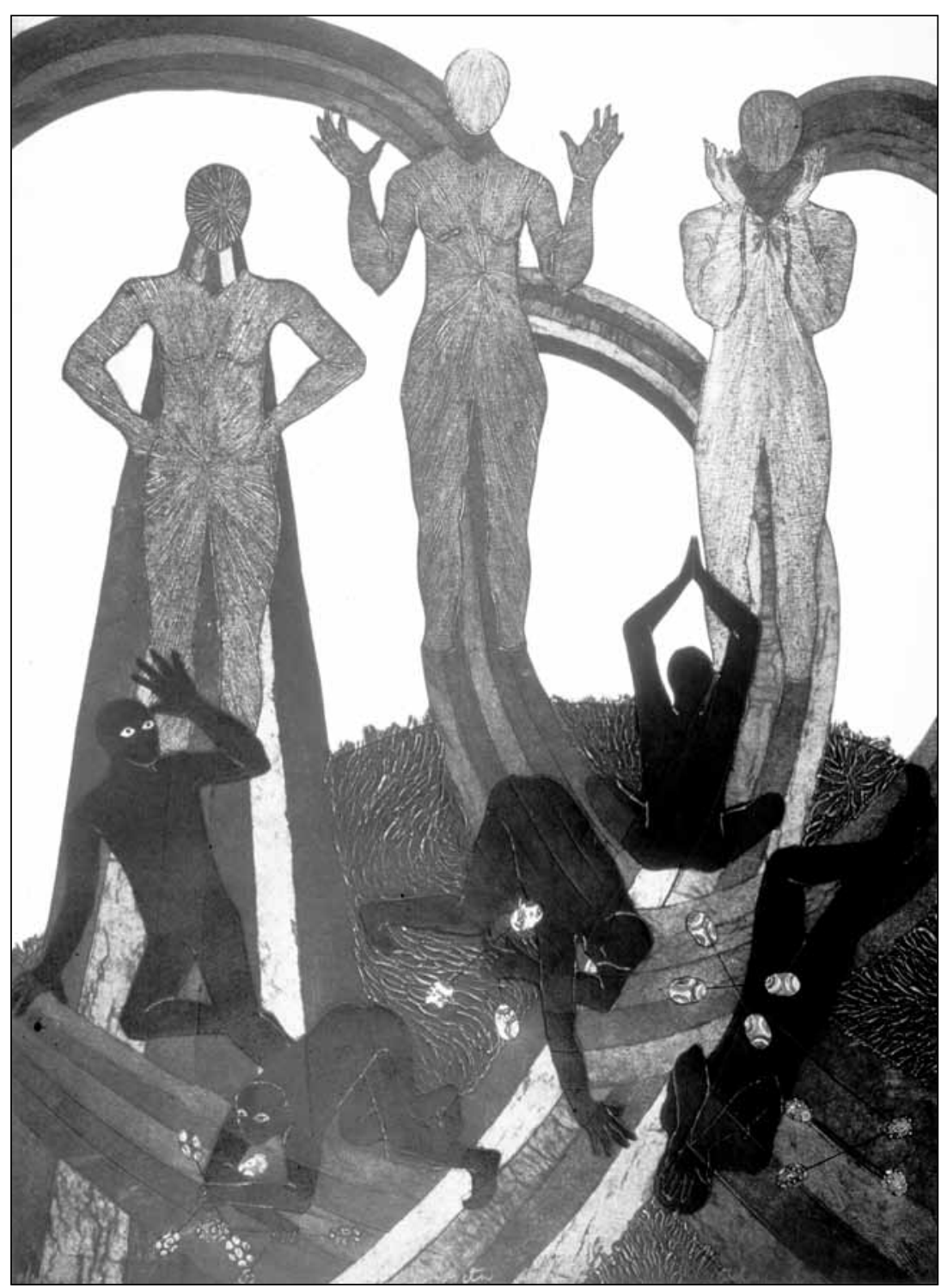

Belkis Ayón. Vindicta. 1993. Colografía. Cortesía Estate Belkis Ayón. 